\title{
Levan Produced by the Halophilic Bacterium Bacillus licheniformis BK1 as a Nanoparticle for Protein Immobilization
}

\author{
Ira Oktavia, Aidah Nur Fithriah, Nur Umriani Permatasari, Enny Ratnaningsih, and Rukman Hertadi*
}

Biochemistry Research Division, Bandung Institute of Technology, Jl. Ganesa No. 10, Bandung 40132, Indonesia

* Corresponding author:

tel: $+62-22-2502103$

email:rukman@chem.itb.ac.id

Received: November 19, 2018

Accepted: April 16, 2019

DOI: $10.22146 /$ ijc. 41064

\begin{abstract}
This study examined the potential of levan from the halophilic bacterium Bacillus licheniformis $B K 1$ as a nanoparticle system for protein immobilization. Levan produced by $\mathrm{B}$. licheniformis BK1 was obtained by incubating the bacterium in the optimized Belghith medium, containing 15\% (w/v) sucrose, 7.5\% (w/v) NaCl and pH 8 , in a rotary shaker at $150 \mathrm{rpm}$ for $16 \mathrm{~h}$, at $40{ }^{\circ} \mathrm{C}$. The structure of the levan produced was verified by FTIR and NMR. It appeared that the levan had the same structure as that from Erwinia herbicola. The obtained levan was then used as a nanoparticle system to immobilize BSA and lysozyme proteins. The BSA-nanoparticle had a non-spherical shape with a surface charge of about $-4.72 \mathrm{mV}$ and a size distribution in the range of 83-298 $\mathrm{nm}$. In contrast, the lysozyme-nanoparticle exhibited more spherical shapes with a surface charge of -2.57 $\mathrm{mV}$ and 206-285 $\mathrm{nm}$ size distribution. The efficiency of immobilization was about $74.26 \%$ and $81.77 \%$ for BSA and lysozyme, respectively. The study thus shows that levan produced by B. licheniformis BK1 can be used as a nanoparticle system for protein immobilization.
\end{abstract}

Keywords: levan; levansucrase; lysozyme-nanoparticle; bovine serum albuminnanoparticle; Bacillus licheniformis $B K 1$

\section{- INTRODUCTION}

Levan is a fructooligosaccharide (fructans) produced by certain types of microorganisms and plants. This biopolymer is a product of transfructosylation and polymerization reactions catalyzed by levansucrase with sucrose as a substrate. Levan is widely used in various industrial fields, such as medicine, food science, and cosmetics. In the medical field, levan has been used as an antitumor agent, an antioxidant, an anti-diabetic agent, an anti-inflammatory agent, and an immunity enhancer [1-5]. In the food science field, this biopolymer has been issued for prebiotics, cake stabilizers and low-calorie sweeteners [3]. In terms of cosmetics, it is used for skin whitening, skin moisturizers and hair care [6].

Levan application has now extended into the field of nanotechnology, where it is used as a material for constructing nanoparticles. Levan produced by E. coli carrying the recombinant levansucrase gene from Bacillus licheniformis has been utilized as a dietary supplement delivery nanoparticle, O-acetyl-a-tocopherol [7]. Levan produced by Acetobacter xylinum NCIM2526 has been used as a nanoparticle system for Au and Ag catalysts [8]. Furthermore, levan isolated from Pseudomonas syringae has been applied as $\mathrm{Co}$, $\mathrm{Fe}$ and Se nanoparticles for dietary supplements. Meanwhile, levan produced by B. polymyxa PTCC1020 was employed as antibacterial nanocomposites and levan produced by Acineto bacternectar has been used to encapsulate 5-fluorouracil for cancer drug delivery systems [9-11].

The above-mentioned levan applications are mostly used for nano-carrier of small particles/molecules. In the previous study, B. licheniformis BK-AG21 was used as a levan producer. However, levan was mostly produced intracellularly instead of extracellular, since levansucrase that catalyzes the levan biosynthesis was not excreted. The advantage of using $B$. licheniformis $\mathrm{BK} 1$, is that the levan is produced extracellularly since the levansucrase produced by this bacterium is excreted. Therefore, levan purification becomes relatively easier. In this study, levan was applied to create a nanoparticle

Ira Oktavia et al. 
for protein immobilization. BSA (Bovine Serum Albumin) and lysozyme were used as protein targets to be immobilized in the nanoparticles. In this study, the levan used was produced by a halophilic bacterium Bacillus licheniformis BK1 indigenous to a salty mud crater, Bledug Kuwu, Central Java, Indonesia. This study began with the optimization of levan production by B. licheniformis BK1 by modifying the production media and growth conditions. Furthermore, the structure of the resulting levan was verified by a spectroscopic method. After that, the levan was used for the production of nanoparticles for the immobilization of BSA and lysozyme. Thus, this study examines the potential of levan derived from the halophilic bacterium Bacillus licheniformis BK1 as a nanoparticle system for protein immobilization.

\section{- EXPERIMENTAL SECTION}

\section{Sources and Nature of Materials}

A levan-producing bacterium, B. licheniformis BK1 indigenous from salty mud crater, Bledug Kuwu, Central Java, Indonesia was obtained from the collection at the biochemistry laboratory, Bandung Institute of Technology, Bandung. BSA and lysozyme, here the target proteins for immobilization, were purchased from Sigma Aldrich. Materials for bacterial growth, such as yeast extract, tryptone, bacto-agar were purchased from Sigma Aldrich, while other components such as $\mathrm{NaCl}$ and $\mathrm{K}_{2} \mathrm{HPO}_{4 \mathrm{~b}}$ were obtained from Merck. Other chemicals, such as DNS (Dinitrosalicyclic) (Sigma Aldrich) and Sucrose (Merck) were used for the activity measurement of levansucrase, $\mathrm{Na}_{2} \mathrm{SO}_{4}$ (Merck) was used for buffer preparation, and ethanol 95\% (Merck) was used for levan extraction and purification.

\section{Procedure}

\section{Potential assay for levan-producing bacteria}

B. licheniformis BK1 was inoculated on a modified Belghith medium containing $20 \%$ of $(\mathrm{w} / \mathrm{v})$ sucrose as a carbon source, $10 \%(\mathrm{w} / \mathrm{v}) \mathrm{NaCl}, 0.5 \%(\mathrm{w} / \mathrm{v})$ as yeast extract, $1 \%(\mathrm{w} / \mathrm{v})$ tryptone and $0.25 \%(\mathrm{w} / \mathrm{v}) \mathrm{K}_{2} \mathrm{HPO}_{4}[12]$. Then the inoculum was incubated at $37{ }^{\circ} \mathrm{C}$ for $24 \mathrm{~h}$. A positive result in this assay was the appearance of a viscous mucus excreted by the bacterial colonies.

\section{Bacterial tolerance assay against salinity level}

B. licheniformis BK1 is a halophilic bacterium, therefore, in order to obtain the optimal growth, it was incubated in a liquid Luria Bertani medium with varying salinity levels. This was achieved by varying $\mathrm{NaCl}$ concentration within the range of $0-15 \%(w / v)$. The bacterium was incubated in a rotary shaking incubator at $37^{\circ} \mathrm{C}, 150 \mathrm{rpm}, 24 \mathrm{~h}$. Bacterial growth was monitored by measuring the optical density with a UV-Vis spectrophotometer at $600 \mathrm{~nm}$ [13].

\section{Optimization of the production of levan}

The other way to identify the potential of $B$. licheniformis BK1 to produce levan is by measuring levansucrase activity. Levansucrase activity was assayed by DNS colorimetric method, in which a unit activity is defined as the amount of enzyme needed to produce 1 $\mu \mathrm{mol}$ glucose resulted from the sucrose hydrolysis per minute [12]. Therefore, the optimization of the enzymatic reaction is a critical step to enhance the levan production rate. This step was carried out by optimizing the production medium compositions, $\mathrm{pH}$, and temperature. B. licheniformis BK1 was grown in the modified Belghith medium with varied $\mathrm{NaCl}$ concentration within the range of $1-20 \%(\mathrm{w} / \mathrm{v}), 1-20 \%(\mathrm{w} / \mathrm{v})$ sucrose concentration, $\mathrm{pH}$ $4-10$, a temperature range of $25-50{ }^{\circ} \mathrm{C}$ and also varying the incubation time. The optimum medium and conditions were then used to produce levan.

\section{Isolation and purification of levan}

Isolation of levan was performed following the method developed by Tabernero et al. [11] with modifications. The modification was made because the original medium composition was made without the addition of $\mathrm{NaCl}$. This study used halophilic bacteria so $\mathrm{NaCl}$ was added to the medium. The obtained culture was heated to boil, then subsequently cooled to room temperature and centrifuged at $7500 \mathrm{rpm}$ for $20 \mathrm{~min}$ at $4{ }^{\circ} \mathrm{C}$. Afterwards, the resulting supernatant and pellet were separated. The collected supernatant was the mixed with 95\% cold ethanol at a ratio of 3:1 (ethanol: supernatant) to precipitate the levan. The mixture was then centrifuged at $9,800 \times \mathrm{g}$ at $4{ }^{\circ} \mathrm{C}$ for $15 \mathrm{~min}$. The obtained levan was washed with $95 \%$ cold ethanol three times and 
$\mathrm{ddH}_{2} \mathrm{O}$ (double distilled water) twice. After that, it was dried in an oven at a temperature of $60^{\circ} \mathrm{C}$ for $4 \mathrm{~h}$.

\section{Characterization of levan structure}

Fourier Transform Infrared (FTIR) spectroscopy. The isolated levan from $B$. licheniformis BK1 was initially characterized using Fourier Transform Infrared (FTIR; Shimadzu IR Prestige-21) in order to identify functional groups that constituted its structure and then compared with a levan standard from $E$. herbicola. Levan was mixed with $\mathrm{KBr}$ in the ratio of 1:100 to make a $\mathrm{KBr}$ pellet of 1 $\mathrm{mm}$ thickness. A spectrum of the sample was taken from the wave number of $4500-500 \mathrm{~cm}^{-1}$.

Nuclear Magnetic Resonance (NMR). The structure of the sample and the levan standard was further verified using ${ }^{1} \mathrm{H}-\mathrm{NMR}$ and ${ }^{13} \mathrm{C}-\mathrm{NMR}$ spectroscopy (JEOL JNMECA 500). The sample of levan was dissolved in $\mathrm{D}_{2} \mathrm{O}$ but the standard levan was dissolved in DMSO for both NMR measurements.

\section{Preparation of protein-levan nanoparticles}

Protein-carrying nanoparticles were prepared by following the method described by Sezer et al. [14]. A total of $0.5 \%(\mathrm{w} / \mathrm{v})$ of the isolated levan was dissolved in $10 \mathrm{~mL}$ $\mathrm{ddH}_{2} \mathrm{O} \mathrm{pH}$ 3.5. Next, $0.1 \%(\mathrm{w} / \mathrm{v})$ of the protein was dissolved in $10 \mathrm{~mL}$ of $20 \%(\mathrm{w} / \mathrm{v}) \mathrm{Na}_{2} \mathrm{SO}_{4}$ solution and then mixed with the Levan solution. In this study, BSA and lysozyme were used as the target protein for immobilization. The mixture was stirred using a magnetic stirrer with the stirring rate of $500 \mathrm{rpm}$ for $20 \mathrm{~h}$ at room temperature. After that, the mixture was centrifuged by $7500 \mathrm{rpm}$ for $20 \mathrm{~min}$ at $4{ }^{\circ} \mathrm{C}$ to separate the pellet and the supernatant. The obtained pellet was washed with $\mathrm{ddH}_{2} \mathrm{O}$ three times and then dried for $2 \mathrm{~h}$.

\section{Characterization of levan nanoparticles}

Morphological analysis. The isolated levan and levanprotein nanoparticles were attached to a carbon adhesive and then gold coated with $10 \mathrm{~mA}$ sputter-coater (Hitachi MC 1000). The sample morphology was analyzed using Scanning Electron Microscopy (SEM; Hitachi SU-3500).

Size distribution analysis and determination of the surface charge. Prior to the measurements, the proteinlevan nanoparticles were dissolved in phosphate buffer $\mathrm{pH}$ 7.3. Nanoparticle size and surface charge were measured with a particle size analyzer (Delsa ${ }^{\text {tw }}$ Nano C Particle Analyzer, Beckman Coulter). The surface charge was expressed in Zeta Potential.

\section{Determination of immobilization efficiency}

Efficiency was determined by measuring protein uptake before and after immobilization using the Bradford method. The concentration of the protein uptake was interpolated on to the BSA standard curve to determine its concentration (Eq. (1)) [15]:

Efficiency of Im mobilization $=\frac{[\mathrm{P}]_{\text {prep }}-[\mathrm{P}]_{\text {sptn }}}{[\mathrm{P}]_{\text {prep }}} \times 100 \%$

\section{- RESULTS AND DISCUSSION}

\section{Test of B. licheniformis BK1 as a Potential Levan Producer}

The result showed that $B$. licheniformis could grow on Belghith medium containing 20\% (w/v) sucrose and supplemented with the halophilic condition $(10 \%$ $\mathrm{NaCl})$. There was thick mucus observed around the medium after $24 \mathrm{~h}$ incubation at $37^{\circ} \mathrm{C}$. It was indicated that $B$. licheniformis $\mathrm{BK} 1$ had great potential as a levan producer (Fig. 1).

\section{Optimization of Levan Production through Levansucrase Characterization}

The first optimization for levansucrase activity was performed by varying the $\mathrm{NaCl}$ concentration of the production medium (liquid Belghith medium) in the range of $1-20 \% \mathrm{NaCl}(\mathrm{w} / \mathrm{v})$. Bacterial growth continued

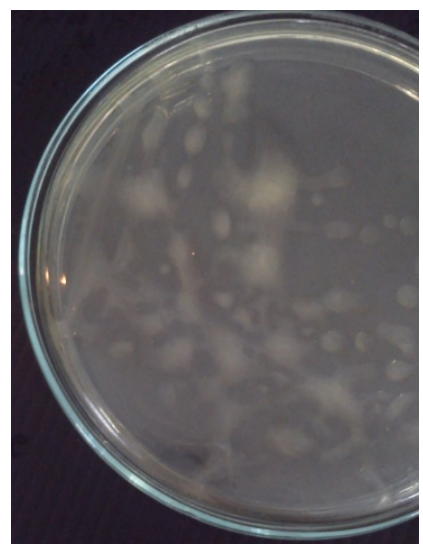

Fig 1. The potential test result for B. licheniformis BK1 as levan producer on Belghith medium 
up to $15 \%(\mathrm{w} / \mathrm{v}) \mathrm{NaCl}$, hence justifying the observation that B. licheniformis BK1 is moderately halophile. The highest activity of levansucrase was observed at $7.5 \%(\mathrm{w} / \mathrm{v}) \mathrm{NaCl}$ (Fig. 2). In the next experiment, concentrations of sucrose in the production medium were varied in the range of $1-20 \%(w / v)$ with optimized $\mathrm{NaCl}$. Both bacterial growth and levansucrase activity were observed after $24 \mathrm{~h}$ of incubation. The results showed that the sucrose tolerance for B. licheniformis BK1 was between 1-15\% (Fig. 3). The specific activity of levansucrase excreted by the bacterium

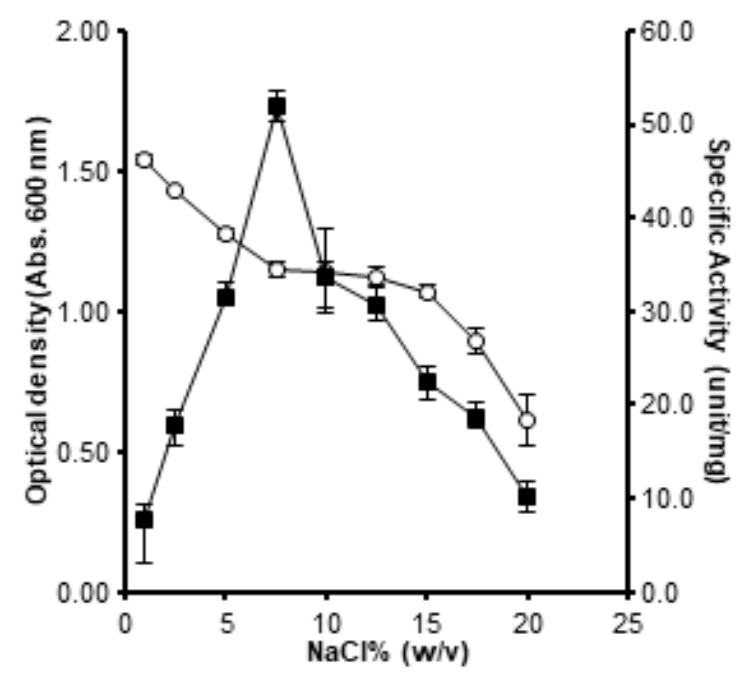

Fig 2. Effect of $\mathrm{NaCl}$ concentration variation on bacterial growth (white circle) and levansucrase activity (black square)

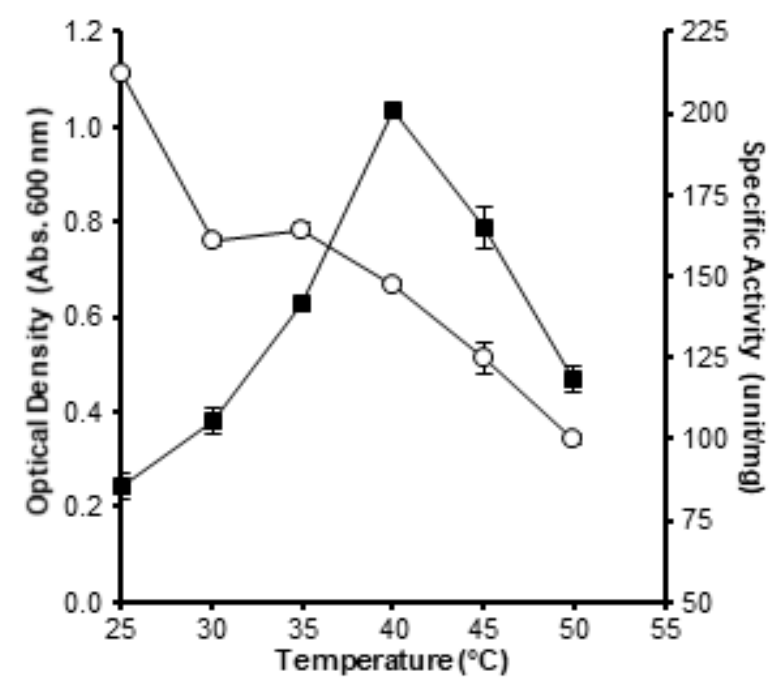

Fig 4. Effect of temperature variation on bacterial growth (white circle) and levansucrase activity (black square) reached the highest value at $15 \%(\mathrm{w} / \mathrm{v})$ of sucrose. For the next test, the previously optimized $\mathrm{NaCl}$ and sucrose were used with varying temperatures, from 25 to $50^{\circ} \mathrm{C}$ in increments of $5^{\circ} \mathrm{C}$. The bacterial growth apparently still continued up to $40{ }^{\circ} \mathrm{C}$, but then decreased sharply above this temperature. Similarly, levansucrase specific activity also exhibited its highest activity at $40^{\circ} \mathrm{C}$ (Fig. 4). Afterwards, B. lichenicormis BK1 was grown at the optimized concentration of $\mathrm{NaCl}$, sucrose, and temperature in a serial medium containing different $\mathrm{pH}$

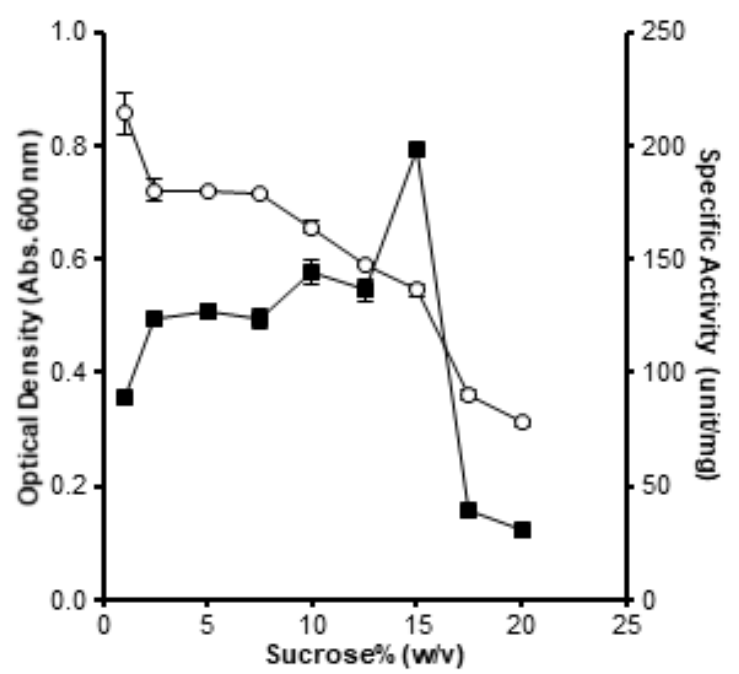

Fig 3. Effect of sucrose concentration variation on bacterial growth (white circle) and levansucrase activity (black square)

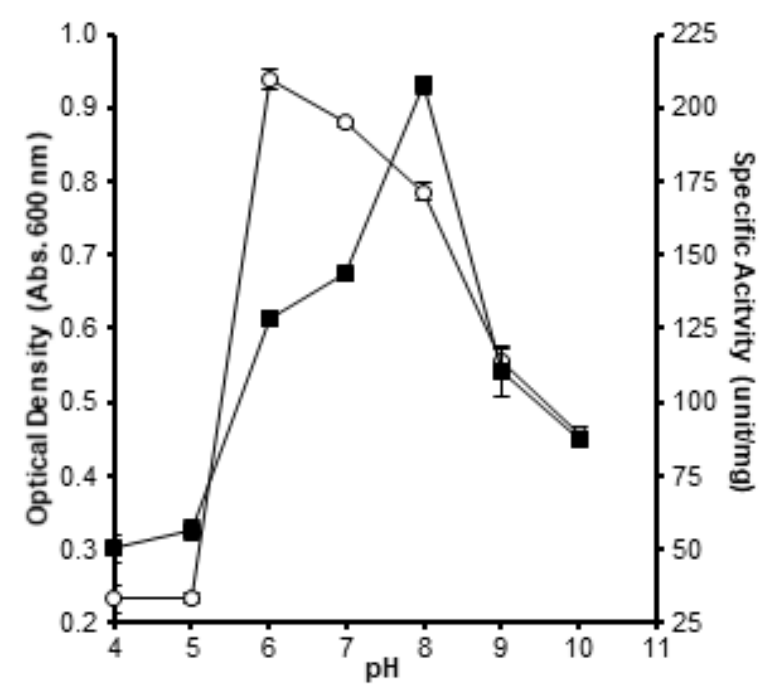

Fig 5. Effect of $\mathrm{pH}$ variation on bacterial growth (white circle) and levansucrase activity (black square) 
from 4 to 10 with an increment of $1 \mathrm{pH}$ unit. Optimum growth reached the highest point at $\mathrm{pH} 6$ but levansucrase activity was observed at $\mathrm{pH} 8$ (Fig. 5).

The result showed that bacterial growth increased in a log phase for $18 \mathrm{~h}$ and reached stationary above $18 \mathrm{~h}$ incubation with $\mathrm{OD}$ value of $1.10 \mathrm{~A}$. The latest log phase showed the highest activity with a value of nearly 220 units/mg and declined dramatically to 40 units/mg above $18 \mathrm{~h}$ incubation (Fig. 6). The enzyme specific activity decreased most likely because, at the stationary phase, protease had been produced to provide additional carbon sources from proteins in the medium.

\section{Characterization of Levan Structures}

The structure of the levan sample isolated from $B$. licheniformis BK1 was elucidated with FTIR and NMR spectroscopic methods and then verified by comparing its spectra with those of a levan standard from E. herbicola (Fig. 7). The FTIR spectrum of the sample revealed the presence of $-\mathrm{OH}$ bond at a wavenumber of $3389 \mathrm{~cm}^{-1},-\mathrm{CH}$ bond at a wavenumber of $2885 \mathrm{~cm}^{-1}, \mathrm{C}-\mathrm{OH}$ bond at a wavenumber of $1018 \mathrm{~cm}^{-1}$, furanose ring at a wavenumber of $1057-1271 \mathrm{~cm}^{-1}$, and fingerprint area at wavenumber of $928-1271 \mathrm{~cm}^{-1}$ (Fig. 7(a)). These functional groups were similar to those of the levan from E. herbicola thereby confirming that both were composed of similar functional groups (Fig. 7(b)).

Further structural verification of the sample was carried out by ${ }^{1} \mathrm{H}-\mathrm{NMR}$ and ${ }^{13} \mathrm{C}-\mathrm{NMR}$. Similar to the above FTIR spectral pattern, the obtained ${ }^{1} \mathrm{H}-\mathrm{NMR}$ spectrum had a similar pattern and chemical shifts with the levan standard from E. herbicola and the other halophilic B. licheniformis BK-AG21 [16] (Table 1). In

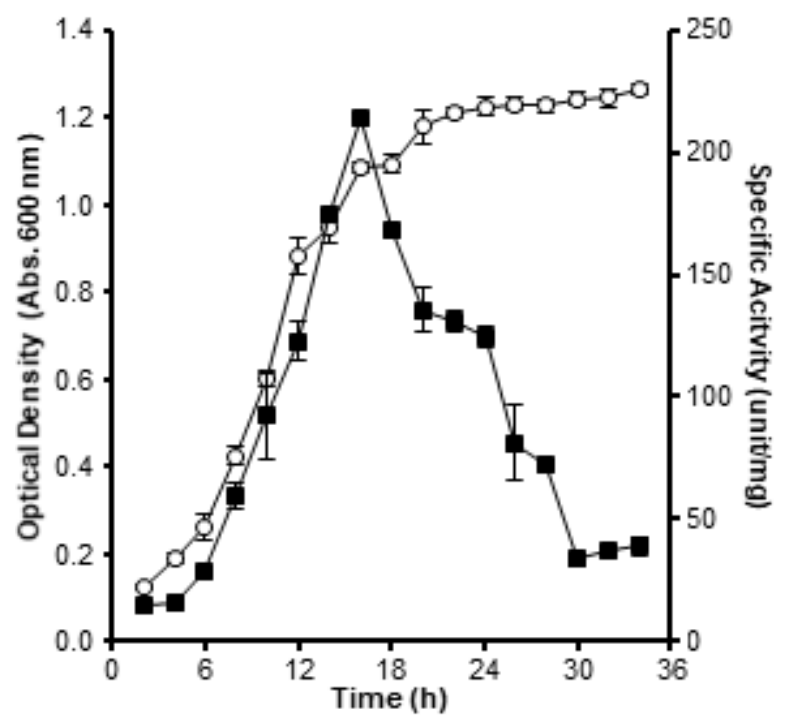

Fig 6. Effect of incubation time on the bacterial growth (white circle) and levansucrase activity (black square)

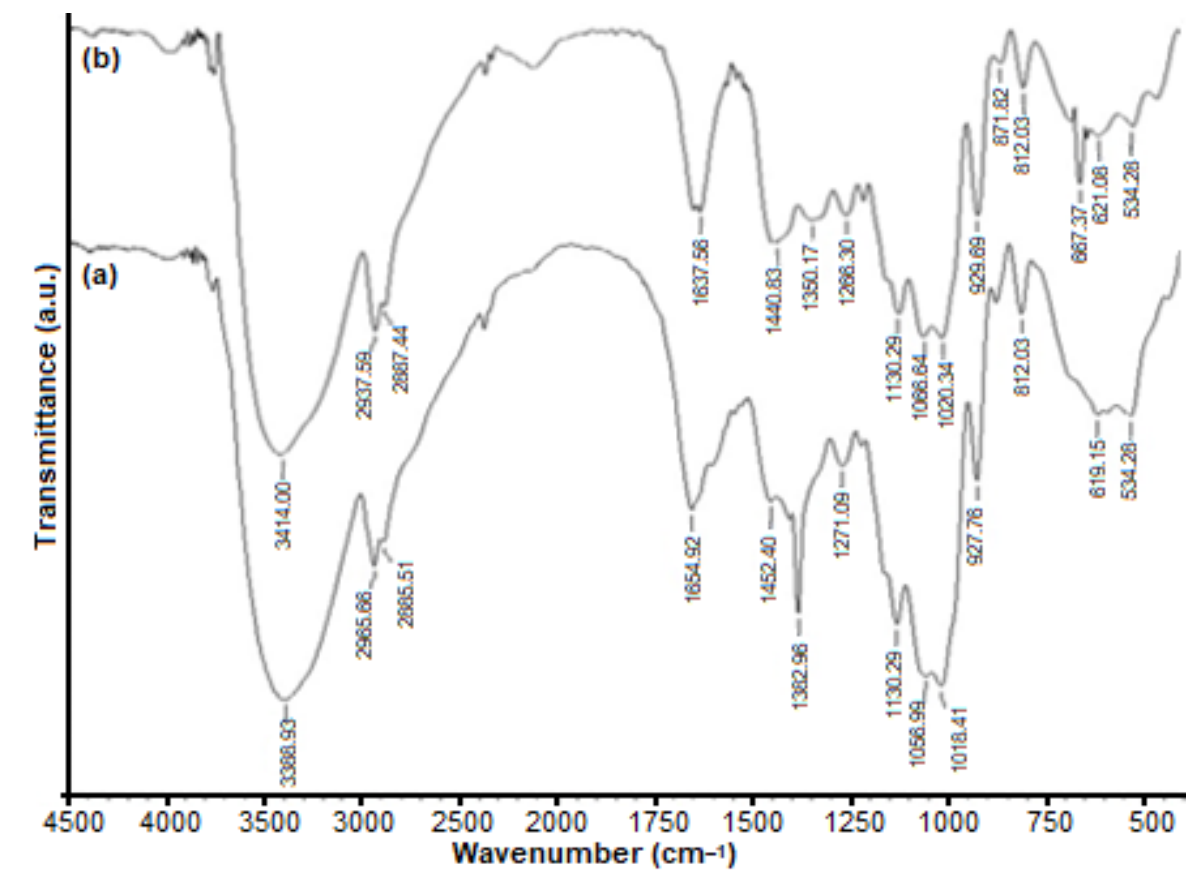

Fig 7. FTIR spectrum of levan from (a) sample of B. licheniformis and (b) standard of E. herbicola 
Table 1. The comparison of ${ }^{1} \mathrm{H}-\mathrm{NMR}$ chemical shifts for levan from B. licheniformis, E. herbicola and B. licheniformis BK AG21

\begin{tabular}{lccc}
\hline \multirow{2}{*}{ Proton } & \multicolumn{3}{c}{ Chemical shifts $(\mathrm{ppm})$} \\
\cline { 2 - 4 } & B. licheniformis BK1 $^{\mathrm{a}}$ & E. herbicola $^{\mathrm{b}}$ & B. licheniformis BK AG21 $^{\mathrm{c}}$ \\
\hline H-1a & $3.64(\mathrm{~d})$ & 3.61 & $3.61(\mathrm{~d})$ \\
H-1b & $3.73(\mathrm{~d})$ & 3.70 & $3.73(\mathrm{~d})$ \\
H-3 & $4.15(\mathrm{~d})$ & 4.72 & $4.15(\mathrm{~d})$ \\
H-4 & $4.06(\mathrm{t})$ & 3.97 & $4.07(\mathrm{t})$ \\
H-5 & $3.89(\mathrm{~m})$ & 3.78 & $3.88(\mathrm{~m})$ \\
H-6 & $3.60(\mathrm{t})$ & 3.43 & $3.34(\mathrm{t})$ \\
\hline
\end{tabular}

${ }^{\star}$ Levan in this study; ${ }^{b}$ Levan standard; ' $L e v a n$ from Mamay et al. [16]

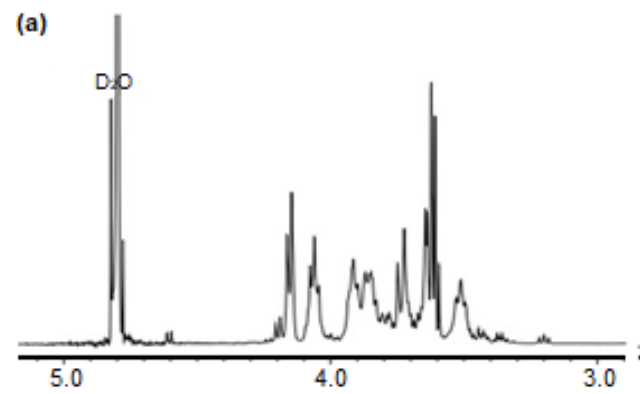

(b)

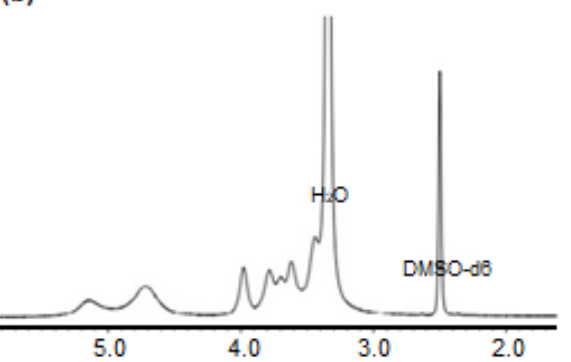

Fig 8. The ${ }^{1} \mathrm{H}-\mathrm{NMR}$ spectra of levan from (a) sample of $B$. licheniformis and (b) standard of E. herbicola

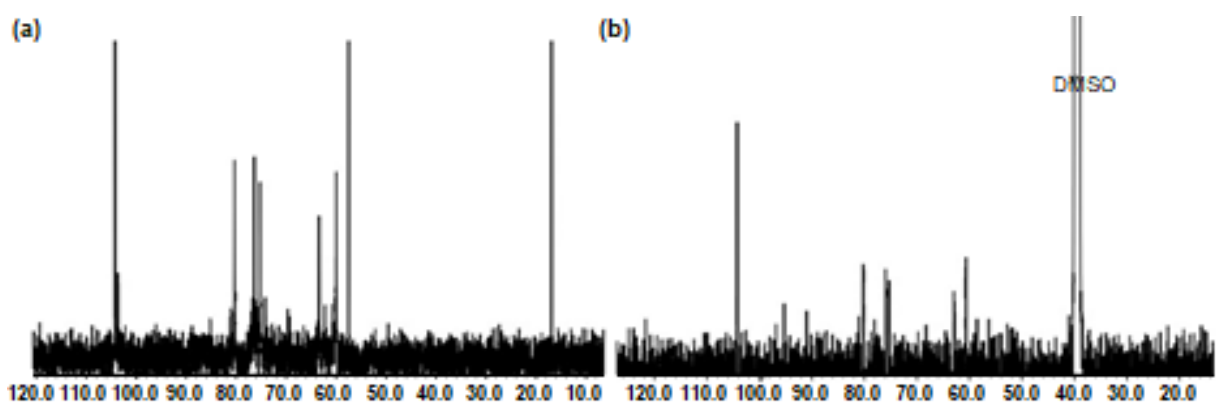

Fig 9. The ${ }^{13} \mathrm{C}-\mathrm{NMR}$ spectra of levan from (a) sample of B. licheniformis and (b) standard of E. herbicola

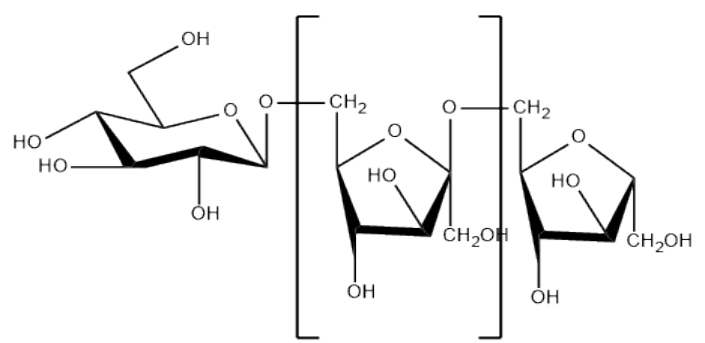

Fig 10. Levan structure

terms of the shape of the sample spectrum, the spectra of levan isolated from B. licheniformis BK1 (Fig. 8(a)) had sharper peaks compared to those of the standard levan (Fig. 8(b)).

Similar to ${ }^{1} \mathrm{H}-\mathrm{NMR}$ result, similar spectral pattern and chemical shifts were observed between the ${ }^{13} \mathrm{C}$ NMR spectrum of the levan sample with those of the $E$. herbicola standard (Fig. 9). The profile was also similar to the reference levan from B. methylotrophicus SK21.002 (Table 2). Based on all of these analyses, the isolated levan from B. licheniformis BK1 was confirmed to be levan with the structure depicted in Fig. 10.

\section{Application of Bacterially Produced Levan as Nanoparticles for Protein Immobilization}

The BSA-levan nanoparticles, as seen in the SEM image, exhibited a non-spherical morphological shape (Fig. 11(a)). The size distribution of these nanoparticles was in the range of $65-298 \mathrm{~nm}$, but most of the 
nanoparticles were around $65 \mathrm{~nm}$ (Fig. 12(a)). The amount of BSA that was successfully immobilized or incorporated into the levan nanoparticles was about $74.26 \%$. In contrast, the SEM image and the size distribution of the lysozymelevan nanoparticles showed more spherical shapes and more homogeneous particle sizes (Fig. 11(b)), which were in the range of 206-285 nm (Fig. 12(b)). Furthermore, the success rate for lysozyme immobilization on the levannanoparticle was also higher at, about $81.75 \%$.
In order to verify the potential of B. licheniformis $\mathrm{BK} 1$ as a levan producer, it was grown on the modified Belghith medium containing 20\% (w/v) sucrose as a major carbon source. Since B. licheniformis BK1 is a moderately halophilic bacterium, it was also added with $10 \%(\mathrm{w} / \mathrm{v}) \mathrm{NaCl}$. The potential of $\mathrm{B}$. licheniformis BK1 as a levan producer can be seen in Fig. 1 and was exhibited by the appearance of a thick mucus secreted by the bacterial cells after $24 \mathrm{~h}$ of incubation at $37^{\circ} \mathrm{C}$. The high

Table 2. The comparison of ${ }^{13} \mathrm{C}-\mathrm{NMR}$ spectral chemical shifts of levan from B. licheniformis, Erwinia herbicola and B. methylotrophicus SK21.002

\begin{tabular}{lccc}
\hline \multirow{2}{*}{ Carbon } & \multicolumn{3}{c}{ Chemical shifts $(\mathrm{ppm})$} \\
\cline { 2 - 4 } & B. licheniformis BK1 $^{\mathrm{a}}$ & E. herbicola $^{\mathrm{b}}$ & B. methylotrophicus SK21.002 $^{\mathrm{c}}$ \\
\hline C-1 & 60.09 & 62.20 & 61.20 \\
C-2 & 104.27 & 105.80 & 102.66 \\
C-3 & 76.26 & 78.60 & 77.51 \\
C-4 & 75.26 & 77.20 & 76.10 \\
C-5 & 80.35 & 81.90 & 80.77 \\
C-6 & 63.44 & 65.00 & 63.94 \\
\hline
\end{tabular}

${ }^{\star a}$ Levan in this study; ${ }^{\mathrm{b}}$ Levan standard in this study; ${ }^{\mathrm{C}}$ Levan from Zhang et al. [17]

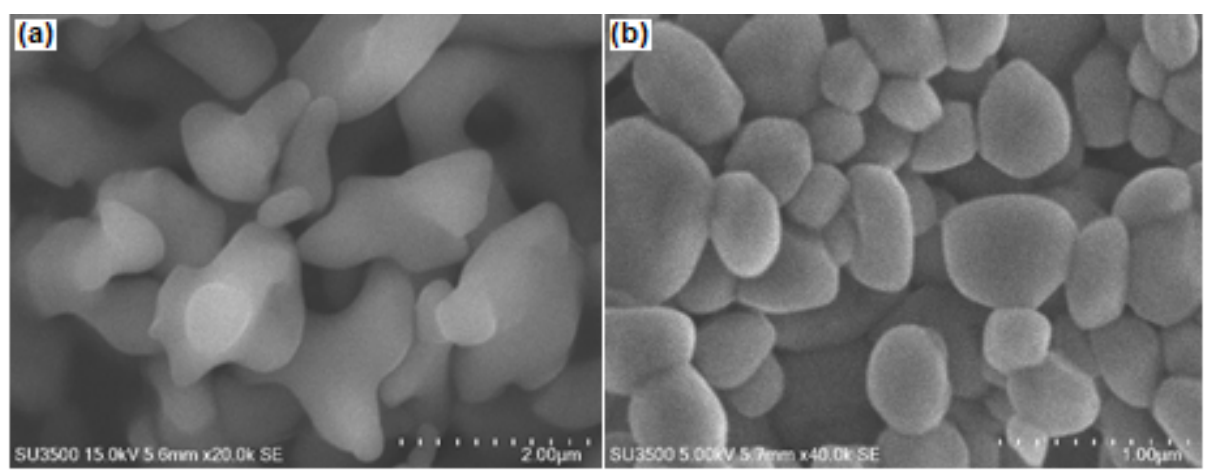

Fig 11. Scanning electron microscope image of the levan-nanoparticle system that interacted with (a) BVA and (b) lysozyme
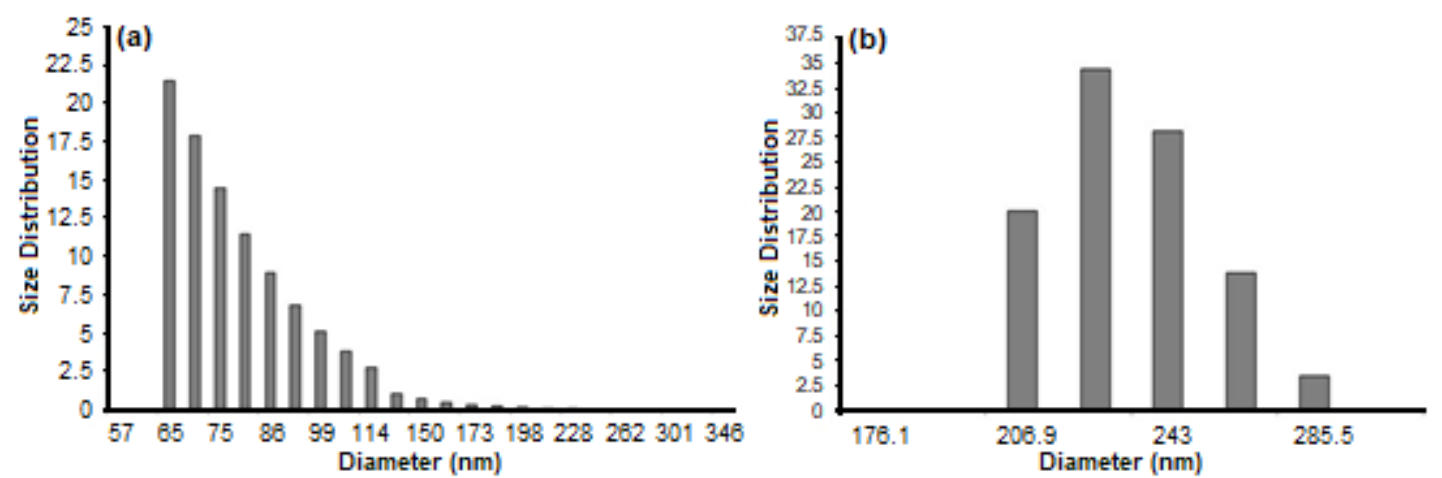

Fig 12. Particle size distribution of the levan-nanoparticle system that interacted with (a) BVA and (b) lysozyme 
sucrose concentration stimulated the bacterial cells to release levansucrase to the medium which would then hydrolyze the sucrose into glucose and fructose and polymerize the fructose to become levan as well as performing uptake of some glucose for its growth [18].

Based on the result, B. licheniformis BK1 was categorized as moderately halophilic. These bacteria could grow up in Belghith medium supplemented with $15 \%$ (w/v) $\mathrm{NaCl}$ but the highest levansucrase activity was observed well at $7.5 \%(\mathrm{w} / \mathrm{v}) \mathrm{NaCl}$. The activity of levansucrase in catalyzing a reaction to produce levan is affected by sucrose concentration, $\mathrm{pH}$, and temperature [3]. In addition, the use of halophilic bacterium in our study must also take into account the medium salinity [19].

This study revealed that levansucrase excretion was at the highest value when the medium was supplemented with $15 \%(\mathrm{w} / \mathrm{v})$ sucrose. This study was in line with previous research that stated that when sucrose concentrations are greater than 10\%, the transfructosylation reaction is preferred for the formation of levan. Concentrations of sucrose higher than 15\% (w/v) apparently inhibited bacterial growth and thereby reduced the amount of enzyme excreted by the bacterium as indicated by a sharp decrease in its specific activity [12]. Therefore, 7.5\% (w/v) $\mathrm{NaCl}$ and 15\% (w/v) of sucrose were used in the next optimization.

All of the above-optimized parameters were then used to optimize the incubation time in the levan production. The bacteria were grown in the optimal production medium for $34 \mathrm{~h}$ and both the growth of the bacteria and the levansucrase specific activity was monitored every two hours. The results, as seen in Fig. 6, showed that the highest levansucrase specific activity was observed at $14 \mathrm{~h}$ of incubation, which was at the transition between the exponential and stationary phases. Levansucrase activity sharply decreased after entering the stationary phase. The enzyme specific activity decreased because, at the stationary phase, it is most likely that protease had been produced to provide additional carbon sources from proteins in the medium. All of the aboveoptimized parameters were used in further levan production by B. licheniformis BK1.
Temperature optimization showed the bacteria was able to grow in the temperature range of $25-50{ }^{\circ} \mathrm{C}$. However, levansucrase activity exhibited the highest value at $40{ }^{\circ} \mathrm{C}$ and declined above that. These statements were supported with another study that stated that transfructosylation reaction of levan formation takes place within the temperature of $10-40{ }^{\circ} \mathrm{C}$ [19]. In addition, the study also showed that the bacterial growth reached the optimum level at $\mathrm{pH} 6$ but levansucrase specific activity exhibited its highest activity at $\mathrm{pH} 8$, which is within the range of the typical $\mathrm{pH}$ conditions for levan formation at $\mathrm{pH}$ 6-9 [12].

In this study, it was found that there were similar functional groups of between the observed levan produced by $B$. licheniformis and the levan standard which was produced by $E$. herbicola. FTIR spectrum revealed the presence of $-\mathrm{OH},-\mathrm{CH}, \mathrm{C}-\mathrm{OH}$, furanose ring, and fingerprint area of the levan from $B$. licheniformis which was similar to that of E. herbicola. The NMR spectrum of ${ }^{1} \mathrm{H}$ and ${ }^{13} \mathrm{C}$ showed chemical shifts although similarities in the pattern could be detected. Spectra of the levan obtained from $B$. licheniformis had sharper peaks compared to those of the levan standard. This is likely due to the difference in chain length, in which the chain length of the sample was relatively shorter than that of the standard. The profile of the levan from B. licheniformis is more similar to the reference levan from B. methylotrophicus SK21.002, as seen in Table 2, rather than the levan standard from $E$. Herbicola [16]. Thus, the levan structure of $B$. licheniformis could be determined and confirmed as shown in Fig. 10.

It has been previously studied that levan has the potential to be developed as a nanomaterial for nanoparticles or nanocarrier of proteins and peptides for drugs or other applications [14]. The levan produced in this study, obtained from B. licheniformis BK1, was evaluated for its potential as a nanoparticle immobilizer for two proteins, BSA and lysozyme. The resulted nanoparticles were characterized by SEM and particle size analyzer to study their morphology, particle size distributions, and surface charge. 
The result showed levan-BSA had a non-spherical shape with a size range of 65-298 nm (most of the nanoparticles were around $65 \mathrm{~nm}$ ), but lysozyme-levan had a spherical shape with a size range of 206-285 $\mathrm{nm}$ and also had higher immobilization rate. The difference in morphology and the immobilization rate of proteins into the levan nanoparticle system was likely due to the difference of protein size. The result of the surface area measurement, calculated by using Getarea program to the crystal structure of both proteins revealed that the surface area of BSA was about $2.69 \times 10^{4} \AA^{2}$, which was significantly larger than that of the lysozyme structure that was only about $6.29 \times 10^{3} \AA^{2}$ [16]. In addition, as revealed from ${ }^{1} \mathrm{H}-\mathrm{NMR}$, levan produced by $B$. licheniformis BK1 on average had a shorter length than those from E. herbicola, such that they could not fully encapsulate the BSA molecular surface as well as the surface of the lysozyme. Therefore, the length of the biopolymer chain and the size of the protein or peptide molecules are critical factors to determine the success rate of producing a levan-nanoparticle system [15,17].

The analysis by using the particle size analyzer revealed that the surface charge value of the levannanoparticle that immobilized BSA and lysozyme were -4.72 and $-2.57 \mathrm{mV}$, respectively. The negative value indicated that the outer surface of the proteins was not yet fully covered by levans. Since the levan-nanoparticle that immobilizes lysozyme had smaller negative value than that of BSA, it was likely that lysozyme surface was more covered than BSA. Sezer had successfully immobilized BSA to a levan nanoparticle, where the levan was produced by Holomonas sp. and obtained a positive surface charge [14]. Therefore, different bacteria may produce levans with different structural characteristics resulting in different morphologies and surface charges.

\section{- CONCLUSION}

Levan produced by $B$. licheniformis BK1 was enhanced in this study through the optimization of levansucrase catalytic performance by varying medium composition and growth conditions. Levan isolated from B. licheniformis $\mathrm{BK} 1$ has a structural feature similar to levan from the other Bacillus sp. and the levan of $E$. herbicola. Levan produced from B. licheniformis BK1 can be used to immobilize proteins which have a molecular size that is similar to or lower than lysozyme. The success rate of levan to form a nanoparticle for protein immobilization depends on the size of the target protein and the average chain length of the levans.

\section{- ACKNOWLEDGMENTS}

The authors thank the Biochemistry Research Division, Study Program of Chemistry, Faculty of Mathematics and Natural Sciences, Bandung Institute of Technology, Indonesia for facilitating this study.

\section{- REFERENCES}

[1] Dahech, I., Belghith, K.S., Hamden, K., Feki, A., Belghith, H., and Mejdoub, H., 2011, Antidiabetic activity of levan polysaccharide in alloxan-induced diabetic rats, Int. J. Biol. Macromol., 49 (4), 742746.

[2] Abdel-Fattah, A.M., Gamal-Eldeen, A.M., Helmy, W.A., and Esawy, M.A., 2012, Antitumor and antioxidant activities of levan and its derivative from the isolate Bacillus subtilis NRC1aza, Carbohydr. Polym., 89 (2), 314-322.

[3] Srikanth, R., Reddy, C.H.S.S.S., Siddartha, G., Ramaiah, M.J., and Uppuluri, K.B., 2015, Review on production, characterization, and applications of microbial levan, Carbohydr. Polym., 120, 102-114.

[4] Srikanth, R., Siddartha, G., Sundhar Reddy, C.H.S.S.S., Harish, B.S., Ramaiah, M.J., and Uppuluri, K.B., 2015, Antioxidant and antiinflammatory levan produced from Acetobacter xylinum NCIM2526 and its statistical optimization, Carbohydr. Polym., 123, 8-16.

[5] Xu, X., Gao, C., Liu, Z., Wu, J., Han, J., Yan, M., and $\mathrm{Wu}, \mathrm{Z}$., 2016, Characterization of the levan produced by Paenibacillus bovis sp. nov BD3526 and its immunological activity, Carbohydr. Polym., 144, 178-186.

[6] Öner, E.T., Hernández, L., and Combie, J., 2016, Review of Levan polysaccharide: From a century of past experiences to future prospects, Biotechnol. $A d v ., 34$ (5), 827-844. 
[7] Nakapong, S., Pichyangkura, R., Ito, K., Iizuka, M., and Pongsawasdi, P., 2013, High expression level of levansucrase from Bacillus licheniformis $\mathrm{RN}-01$ and synthesis of levan nanoparticles, Int. J. Biol. Macromol., 54, 30-36.

[8] Ahmed, K.B.A., Kalla, D., Uppuluri, K.B., and Anbazhagan, V., 2014, Green synthesis of silver and gold nanoparticles employing levan, a biopolymer from Acetobacter xylinum NCIM 2526, as a reducing agent and capping agent, Carbohydr. Polym., 112, 539-545.

[9] Bondarenko, O.M., Ivask, A., Kahru, A., Vija, H., Titma, T., Visnapuu, M., Joost, U., Pudova, K., Adamberg, S., Visnapuu, T., and Alamäe, T., 2015, Bacterial polysaccharide levan as stabilizing, nontoxic and functional coating material for microelement-nanoparticles, Carbohydr. Polym., 136, 710-720.

[10] Taran, M., Etemadi, S., and Safaei, M., 2017, Microbial levan biopolymer production and its use for the synthesis of an antibacterial iron(II,III) oxide-levan nanocomposite, J. Appl. Polym. Sci., 134 (12), 44613.

[11] Tabernero, A., González-Garcinuño, Á., SánchezÁlvarez, J.M., Galán, M.A., and del Valle, E.M.M., 2017, Development of a nanoparticle system based on a fructose polymer: Stability and drug release studies, Carbohydr. Polym., 160, 26-33.

[12] Belghith, K.S., Dahech, I., Belghith, H., and Mejdoub, H., 2012, Microbial production of levansucrase for the synthesis of fructooligosaccharides and levan, Int. J. Biol. Macromol., 50 (2), 451-458.
[13] McBirney, S.E., Trinh, K., Wong-Beringer, A., and Armani, A.M., 2016, Wavelength-normalized spectroscopic analysis of Staphylococcus aureus and Pseudomonas aeruginosa growth rates, Biomed. Opt. Express, 7 (10), 4034-4042.

[14] Sezer, A.D., Kazak, H., Öner, E.T., and Akbua, J., 2011, Levan-based nanocarrier system for peptide and protein drug delivery: Optimization and influence of experimental parameters on the nanoparticle characteristics, Carbohydr. Polym., 84 (1), 358-363.

[15] Sezer, A.D., Sarılmışer, H.K., Rayaman, E., Çevikbaş, A., Öner, E.T., and Akbuğa, J., 2017, Development and characterization of vancomycinloaded levan-based microparticular system for drug delivery, Pharm. Dev. Technol., 22 (5), 627-634.

[16] Mamay, Wahyuningrum, D., and Hertadi, R., 2015, Isolation and characterization of levan from moderate halophilic bacteria Bacillus licheniformis BK AG21, Procedia Chem., 16, 292-298.

[17] Zhang, T., Li, R., Qian, H., Mu, W., Miao, M., and Jiang, B., 2014, Biosynthesis of levan by levansucrase from Bacillus methylotrophicus SK 21.002, Carbohydr. Polym., 101, 975-981.

[18] Li, W., Yu, S., Zhang, T., Jiang, B., and Mu, W., 2015, Recent novel applications of levansucrases, Appl. Microbiol. Biotechnol., 99 (17), 6959-6969.

[19] Ebel, C., Madern, D., and Zaccai, G., 2009, "Molecular Adaptation of Halophilic Proteins" in Extremophiles, vol. II, Eds., Gerday, C., and Glandsdorff, N., Eolss Publisher Co. Ltd., Oxford, England. 